\title{
BLEEDING PEPTIC ULCER - TERTIARY CENTER EXPERIENCE: EPIDEMIOLOGY, TREATMENT AND PROGNOSIS
}

\author{
Ivan Budimir ${ }^{1}$, Sanja Stojsavljević ${ }^{1}$, Davor $\operatorname{Hrabar}^{1}$, Dominik Kralj ${ }^{1}$, Alen Bišćanin ${ }^{1}$, \\ Lora Stanka Kirigin ${ }^{2}$, Mario Zovak ${ }^{3}$ Žarko Babićc ${ }^{4}$, Sven Bohnec ${ }^{5}$ and Ivan Budimir Jr ${ }^{6}$
}

${ }^{1}$ Division of Gastroenterology, Department of Internal Medicine, Sestre milosrdnice University Hospital Center,

School of Medicine and School of Dental Medicine, University of Zagreb, Zagreb, Croatia;

${ }^{2}$ Division of Endocrinology, Department of Internal Medicine, Sestre milosrdnice University Hospital Center,

School of Medicine and School of Dental Medicine, University of Zagreb, Zagreb, Croatia;

${ }^{3}$ Department of Surgery, Sestre milosrdnice University Hospital Center, School of Medicine and School of Dental Medicine, University of Zagreb, Zagreb, Croatia; ${ }^{4}$ Division of Gastroenterology,

Department of Internal Medicine, Dubrava University Hospital, Zagreb, Croatia;

${ }^{5}$ Gastronterologie, Allgemeine Innere Medizin und Geriatrie, Rems-Murr Klinik Winnenden, Winnenden,

Germany; ${ }^{6}$ Magdalena Department of Cardiovascular Diseases, Osijek School of Medicine, Krapinske Toplice, Croatia

\begin{abstract}
SUMMARY - The aim of this study was to demonstrate epidemiological, clinical and endoscopic characteristics of acute upper gastrointestinal bleeding (UGIB) with special reference to peptic ulcer bleeding (PUB). The study included 2198 consecutive patients referred to our emergency department due to acute UGIB from January 2008 to December 2012. All patients underwent urgent upper GI endoscopy within 24 hours of admission, and 842 patients diagnosed with PUB were enrolled and prospectively followed-up. The cumulative incidence of UGIB was 126/100,000 in the 5-year period. Two out of five patients had a bleeding peptic ulcer; in total, $440(52.3 \%)$ had bleeding gastric ulcer, $356(42.3 \%)$ had bleeding duodenal ulcer, 17 (2\%) had both bleeding gastric and duodenal ulcers, and $29(3.5 \%)$ patients had bleeding ulcers on gastroenteric anastomoses. PUB was more common in men. The mean patient age was 65.9 years. The majority of patients (57\%) with PUB were taking agents that attenuate the cytoprotective function of gastric and duodenal mucosa. Rebleeding occurred in 77 (9.7\%) patients and 47 (5.9\%) patients required surgical intervention. The 30-day morality was $5.2 \%$ and $10 \%$ of patients died from uncontrolled bleeding and concomitant diseases. In conclusion, PUB is the main cause of UGIB, characterized by a significant rebleeding rate and mortality.
\end{abstract}

Key words: Gastrointestinal hemorrhage - epidemiology; Gastrointestinal hemorrhage - therapy; Peptic ulcer hemorrhage - epidemiology; Peptic ulcer hemorrhage - therapy; Endoscopy, gastrointestinal; Prognosis; Tertiary care centers; Croatia

\section{Introduction}

Upper gastrointestinal bleeding (UGIB) is a common medical emergency and accounts for $5 \%$ of emergency department presentations per year and $2 \%$ to $3 \%$ of hospital admissions in developed countries ${ }^{1}$. The incidence rate of UGIB varies from 48 to 160 cases per 100,000 population, with consistent reports of higher
Correspondence to: Sanja Stojsavljević, MD, Division of Gastroenterology, Department of Internal Medicine, Sestre milosrdnice University Hospital Center, Vinogradska c. 29, HR-10000 Zagreb, Croatia

E-mail: sanja.stojsavljevic1@gmail.com

Received May 5, 2017, accepted June 7, 2017 
incidence among men and the elderly ${ }^{2}$. The most common cause of acute UGIB is non-variceal, where peptic ulcer bleeding (PUB) accounts for $28 \%$ to $59 \%$ of cases $^{2-4}$.

Endoscopy has become the standard of care in the diagnosis and treatment of UGIB. Most national and international guidelines recommend performing upper endoscopy within 24 hours of presentation in patients with $\mathrm{UGIB}^{5-7}$. Despite major advances in diagnostic and therapeutic approaches, PUB remains a significant problem and an important cause of morbidity and mortality. Rebleeding after initial hemostasis occurs in $10 \%$ to $30 \%$ of patients with PUB $^{8-11}$. The reported PUB mortality rates in various countries across $\mathrm{Eu}-$ rope range from $3.4 \%$ to $14 \%$, and the reason for this difference remains unknown ${ }^{12-15}$.

The aim of this prospective study was to determine the epidemiological, clinical and endoscopic characteristics of UGIB with a focus on the treatment and prognosis of PUB in a tertiary care center.

\section{Patients and Methods}

This prospective study was conducted in a tertiary care center in the City of Zagreb, Croatia, which covers a population of approximately 300,000 people. All consecutive patients presenting with UGIB (hematemesis, melena, hematochezia or blood admixture upon nasogastric aspiration) to the Emergency Internal Medicine Unit, Sestre milosrdnice University Hospital Center between January 2008 and December 2012 were included. These patients were then, if necessary, hospitalized in the Interventional Gastroenterology Unit of the same hospital. If the same patient was hospitalized more than once during the study period, only the first episode was counted as the incident case, irrespective of previous or subsequent episodes of PUB.

Upper gastrointestinal endoscopy was performed in all patients within 24 hours of hospital admission. Only patients with PUB confirmed by endoscopy were prospectively followed-up for 30 days. After initial endoscopic examination, patients in whom endoscopic therapy had been performed were hospitalized. All patients received high-dose acid suppression therapy (pantoprazole or esomeprazole $80 \mathrm{mg}$ intravenously as an initial bolus followed by $40 \mathrm{mg}$ intravenously and/ or oral 3 times per day for at least 48 hours, followed by $40 \mathrm{mg}$ daily per os).
Prior to endoscopy, a written informed consent was obtained from all patients or their relatives, which included possible risks, benefits and treatment options during the procedure. In addition, a written informed consent was obtained from patients or their relatives before trial entry. The study was approved by the Ethics Committee of the hospital. Data were collected prospectively into a database, with patient details stored in a depersonalized manner to protect patient confidentiality.

\section{Data collection}

The following data were collected for each patient: demographic data, signs and characteristics of the bleeding episode, symptoms and history of ulcer or liver disease, coexisting illness, drug use, laboratory results, endoscopic diagnosis including the cause of bleeding, presence of fresh blood/clots or stigmata of recent hemorrhage, endoscopic intervention, medical treatment, rebleeding incidence, surgical therapy, duration of hospitalization and cause of death. Shock was defined as syncope or signs of shock upon physical examination, including systolic blood pressure $<100 \mathrm{~mm}$ $\mathrm{Hg}$ or heart rate $>100$ beats $/ \mathrm{min}$.

Grading of overall health and comorbidity was performed according to the American Society of Anesthesiology (ASA) classification (grade 1, normal healthy patients; grade 2, mild systemic illness; grade 3 , severe, but incapacitating systemic illness; and grade 4 , life-threatening illness). Stigmata of recent hemorrhage were defined according to Forrest classification as follows: Forrest Ia, spurting bleeding; Forrest Ib, oozing bleeding; Forrest IIa, non-bleeding visible vessel; Forrest IIb, adherent clot; Forrest IIc, hematin on ulcer base; and Forrest III, clean ulcer base ${ }^{16}$. The size of ulcer was classified as $<2 \mathrm{~cm}$ or $\geq 2 \mathrm{~cm}$. The commonly used hemostatic procedures were epinephrine injections (1:10000 solution of epinephrine) and/or mechanical hemostasis with stainless steel hemoclips (Olympus, Japan) and/or thermocoagulation with a heater probe (Olympus, 7F, 20-30 joules).

Two biopsy specimens were obtained from the gastric antrum and body in all patients and the presence of Helicobacter pylori ( $H$. pylori) infection was assessed by histopathologic examination of the specimens using hematoxylin-eosin (HE) stain. In all patients with gastric ulcers in whom recurrent bleeding was not observed, follow-up endoscopy was performed four to five days after initial hemostasis and biopsy specimens were ob- 


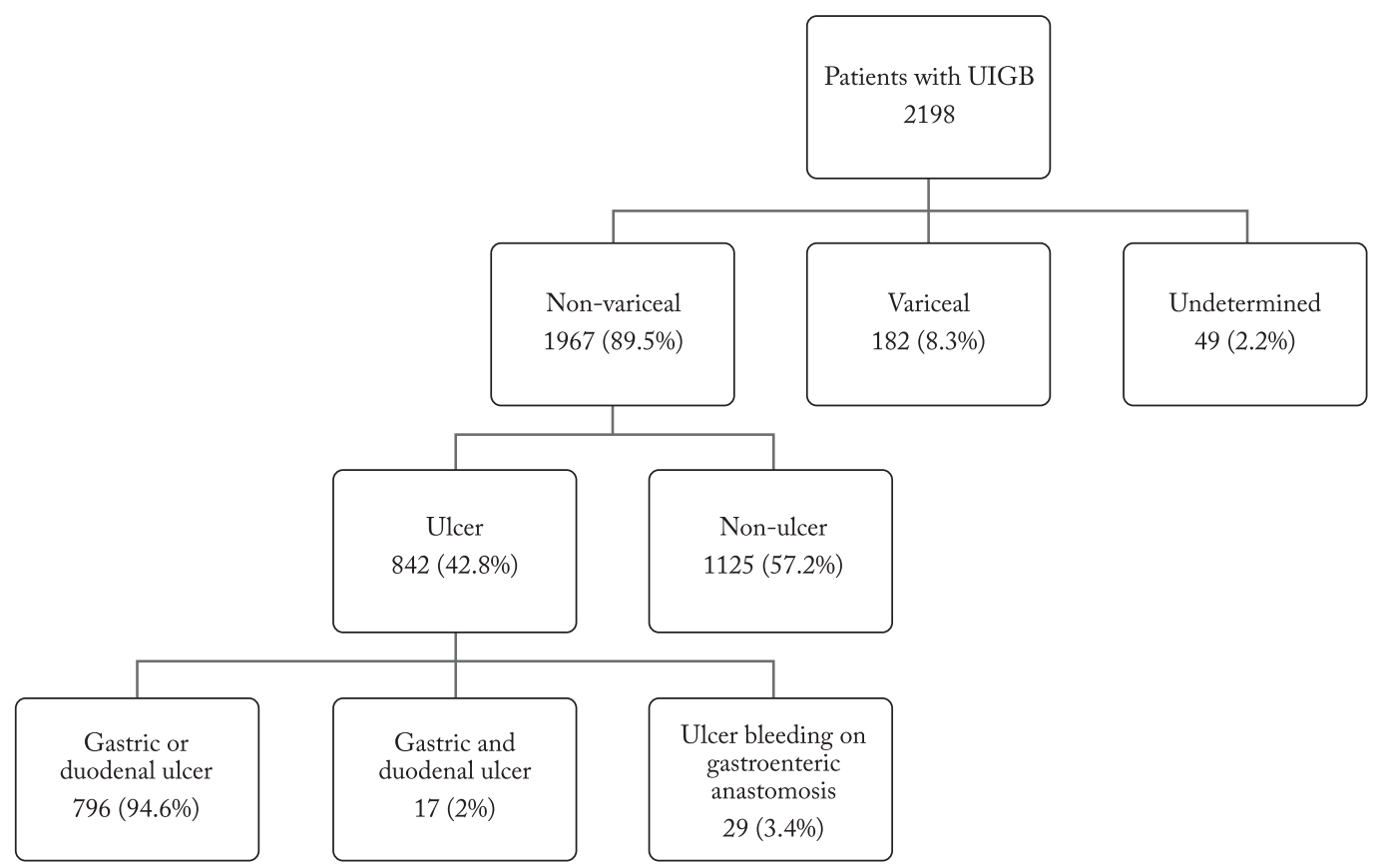

Fig. 1. Patients with upper gastrointestinal bleeding (UGIB) from 2008 to 2012.

tained from the margins and base of gastric ulcers to exclude malignancy. Follow-up endoscopy with histology was planned in all patients with gastric ulcers. In all patients with negative histology for $H$. pylori at index endoscopy, urea breath test (UBT) or follow-up endoscopy with histology was performed 2 weeks after proton pump inhibitor (PPI) treatment had been discontinued. Patients were considered positive for $H$. pylori infection in case of positive histology or positive UBT.

Clinical outcomes of PUB were analyzed according to the rebleeding rate, need for surgical intervention, need for blood transfusion, length of hospital stay, and 30-day mortality.

Rebleeding was defined as one or more signs of ongoing bleeding, including fresh hematemesis or melena, hematochezia, aspiration of fresh blood via nasogastric tube, instability of vital signs, and reduction of hemoglobin or hematocrit levels by more than $2 \mathrm{~g} / \mathrm{dL}$ or $5 \%$, respectively, over a 24 -hour period after primary bleeding was stopped. Patients that had unsuccessful initial endoscopic treatment or more than two successful retreatments underwent emergency surgery.

\section{Statistics}

All analyses were performed with the Statistica 11.0 (Statsoft, Inc., Tulsa, OK) for Windows statistical package. The Mann-Whitney U-test and KruskalWallis ANOVA test were used as nonparametric tests where appropriate, and a p-value $<0.05$ was considered significant. The predictive value of qualitative variables on mortality and rebleeding was studied in univariate analysis using Pearson $\chi^{2}$-test, when appropriate. Multivariate analysis was conducted using a forward elimination logistic regression model to identify a final set of variables independently associated with either mortality or rebleeding. A significance level $\alpha=0.05$ was used to retain variables in the multivariate model. All results were presented as odds ratios (ORs) with the associated $95 \%$ confidence intervals ( $95 \% \mathrm{CIs}$ ).

\section{Results}

From January 2008 to December 2012, 2198 patients with UGIB were analyzed; $89.5 \%$ of patients had non-variceal bleeding, $8.3 \%$ had variceal bleeding, and in $2.2 \%$ the source was not identified.

In the group of patients with non-variceal bleeding, $42.8 \%$ had bleeding ulcer, while $57.2 \%$ had nonulcer bleeding (Mallory-Weis tear, angiomata, Dieulafoy's lesion, malignancy, acute erosive gastropathy, reflux esophagitis, portal hypertensive gastropathy, arterial enteric fistula). In patients with bleeding ulcers, 
Table 1. Clinical and endoscopic characteristics of patients at study entry

\begin{tabular}{|l|l|}
\hline & $\mathrm{n}(\%)$ \\
\hline $\begin{array}{l}\text { Age (yrs) } \\
<65\end{array}$ & $358(45)$ \\
$65-80$ & $300(37.7)$ \\
$>80$ & $138(17.3)$ \\
Gender (male/female), n (\%) & $501(62.9) / 295(37.1)$ \\
Hb level median (range), g/L & $93.9(26-182)$ \\
\hline Findings at endoscopy & $440(55.3)$ \\
Gastric ulcers & $356(44.7)$ \\
Duodenal ulcers & $414(52)$ \\
High-risk ulcers & \\
(Forrest Ia-IIb) & $382(48)$ \\
Low- risk ulcers & \\
(Forrest IIc-III) & \\
Ulcer size, n (\%) & $696(87.4)$ \\
$\quad<2$ cm & $100(12.6)$ \\
22cm & $77(9.7)$ \\
Shock & $220 / 531(41.4)$ \\
Helicobacter pylori & $110(13.9)$ \\
\hline Comorbidity (ASA class) & $225(28.2)$ \\
ASA I & $461(57.9)$ \\
ASA II & $225(28.3)$ \\
ASA III-IV & $162(20.3)$ \\
\hline $\begin{array}{l}\text { Medication } \\
\text { NSAIDs } \\
\text { Acetylsalicylic acid } \\
\text { Antiaggregation therapy } \\
\text { Anticoagulant therapy } \\
\text { Proton pump inhibitors } \\
\text { or H2 blockers }\end{array}$ & $46(5.8)$ \\
\hline
\end{tabular}

$\mathrm{Hb}=$ hemoglobin; ASA = American Society of Anesthesiology; NSAIDs $=$ nonsteroidal anti-inflammatory drugs

94.6\% of cases were attributed to gastric or duodenal ulcers, $2 \%$ to both gastric and duodenal ulcers, and $3.4 \%$ to ulcer on previous gastroenteric anastomoses (Fig. 1).

The cumulative incidence of UGIB in the observed 5 -year period was $126 / 100,000$. In the group of 796 patients that were carefully followed-up, $55.3 \%$ had bleeding from gastric ulcers and $44.7 \%$ from duodenal ulcers. The mean patient age was 65.9 years and men
Table 2. Endoscopic therapy and clinical outcomes

\begin{tabular}{|l|l|}
\hline & $\mathrm{n}(\%)$ \\
\hline Treatment & \\
Endoscopic therapy & $465(58.4)$ \\
Initial hemostasis & $411(51.6)$ \\
\hline Types of initial hemostasis & \\
Epinephrine & $164(39.9)$ \\
Endoclips & $81(19.7)$ \\
Epinephrine + endoclips & $142(34.6)$ \\
Heater probe & $17(4.1 \%)$ \\
Heater probe + epinephrine & $7(1.7 \%)$ \\
\hline Outcome & \\
Rebleeding & $77(9.7)$ \\
30-day mortality & $41(5.2)$ \\
Blood transfusion & $394(49.5)$ \\
Surgery & $47(5.9)$ \\
Median hospital stay (days, range) & $6(0-45)$ \\
\hline
\end{tabular}

had a higher incidence of bleeding (62.9\% vs. 37.1\%; $\mathrm{p}<0.001)$. High risk ulcers (Forrest Ia-IIb) were verified in $52 \%$ of patients, most ulcers were $>2 \mathrm{~cm}$ in diameter, $9.7 \%$ of patients presented with shock, and $57.9 \%$ of patients had moderate to severe comorbidities. When analyzed according to medication usage, $28.3 \%$ of patients with peptic ulcers had been taking non-steroidal anti-inflammatory drugs (NSAIDs), $20.3 \%$ acetylsalicylic acid, $2.6 \%$ anti-aggregation medication, $5.8 \%$ anti-coagulation therapy, and $9.2 \%$ gastroprotective medication (histamine 2 blockers or PPI). H. pylori testing was performed in 531 (66.7\%) patients of which 220 (41.4\%) tested positive. The presence of $H$. pylori infection was more common in patients with duodenal peptic ulcer (46.7\% vs. 36.9\%), which was statistically significant $(\mathrm{p}<0.023)$ (Table 1$)$.

Endoscopic treatment was performed in 456 (58.4\%) patients; in $54.3 \%$ of cases hemostasis was achieved with hemoclips or with a combination of hemoclips and diluted epinephrine infiltration. Rebleeding occurred in $9.7 \%$ of patients (Table 2).

The risk of rebleeding was increased in patients with shock [OR 5.85 (CI 95\% 3.01-11.37)], bleeding ulcer Forrest Ia type [OR 6.48 (CI 95\% 3.12-13.48)] and ulcers $>2 \mathrm{~cm}$ in diameter [OR 2.79 (CI 95\% 1.495.20)] (Fig. 2).

Forty-seven (5.9\%) patients were transferred to the Department of Surgery (5 due to successful endoscop- 


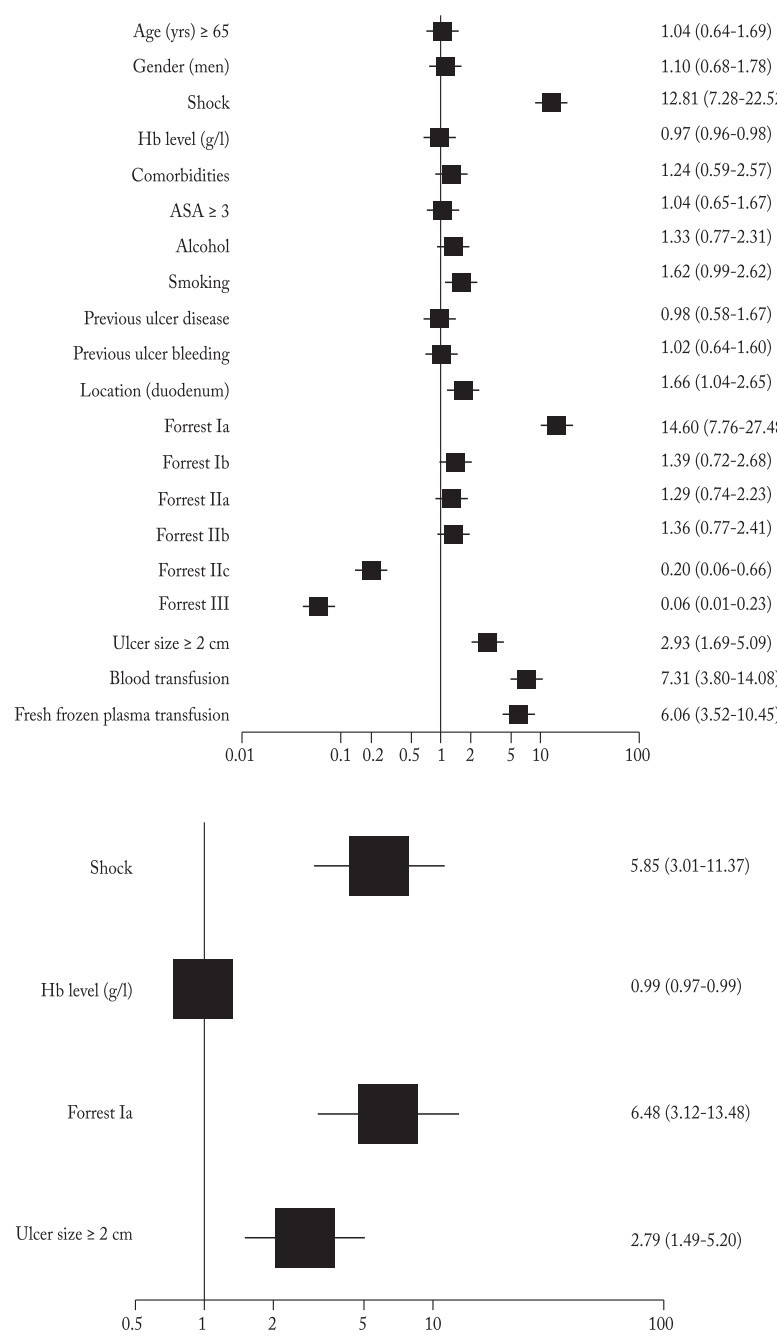

Fig. 2. Univariate and multivariate factors influencing rebleeding in 796 patients with bleeding peptic ulcer.

ic hemostasis, 1 due to perforation during the procedure, and 41 due to recurrent bleeding). Most of the transferred patients had bleeding from the posterior wall of the duodenum, posterior proximal third of the gastric corpus, and from the small gastric curvature. The most common surgical procedure performed was mechanical hemostasis (ligation) and gastric resection. The total 30-day mortality was $5.2 \%$. The risk of lethal outcome was increased in patients with shock [OR 2.74 (CI 95\% 1.19-6.33)], recurrent bleeding [OR 3.54 (CI 95\% 1.59-7.88)], ulcers $>2 \mathrm{~cm}$ in diameter [OR 3.08 (CI 95\% 1.50-6.33)] and moderate to severe comorbidities (ASA $\geq 3$ ) [OR 6.32 (CI 95\% 2.3816.7)] (Fig. 3).

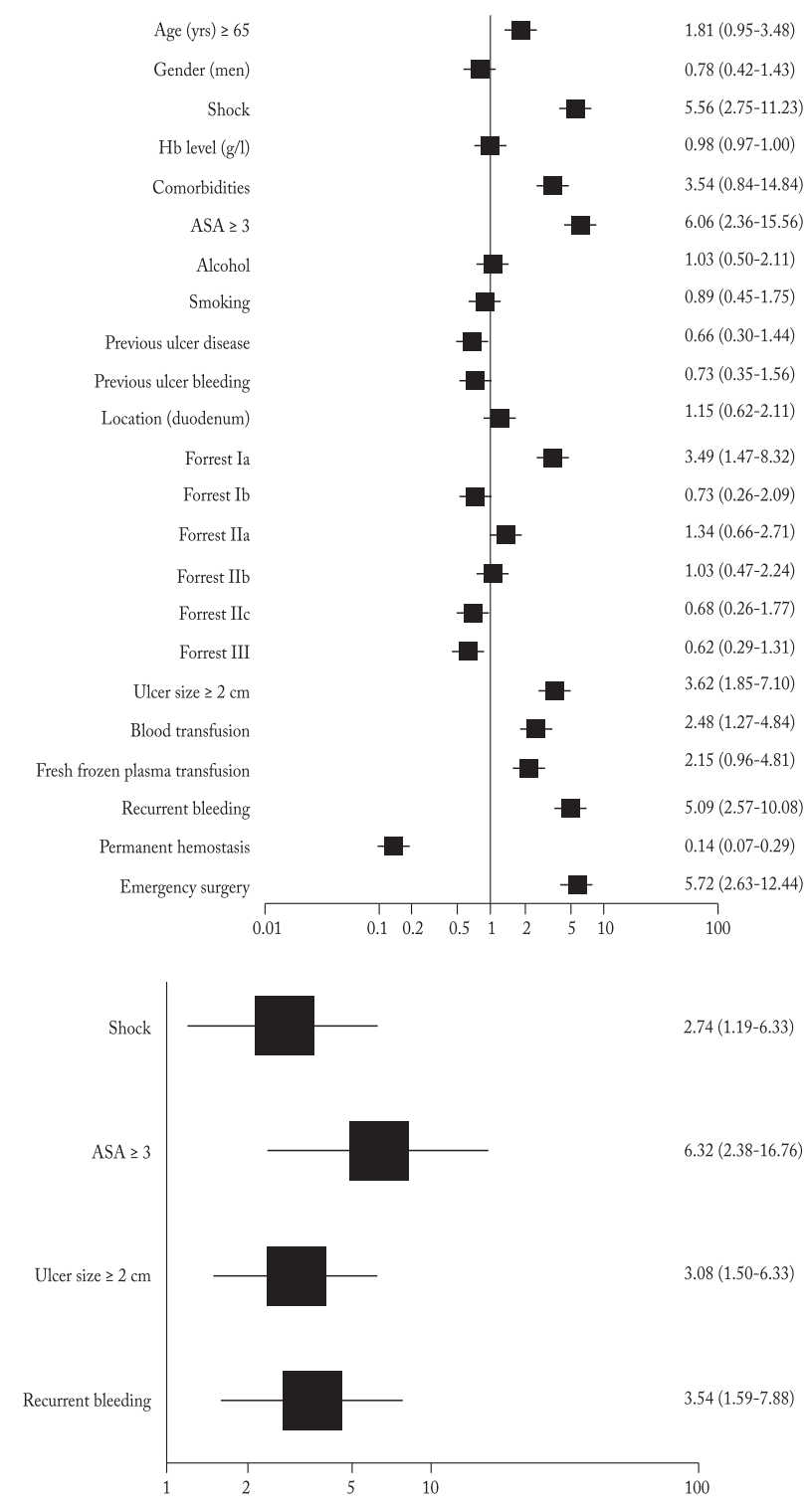

Fig. 3. Univariate and multivariate factors influencing mortality in 796 patients with bleeding peptic ulcer.

Only $1 / 10$ patients died from bleeding out and half of them were treated with red blood cell transfusions. The median volume of red blood cell transfusion was 2.2 (1-6) units and the median hospital stay was 6 (145) days (Table 2).

\section{Discussion}

There has been a significant decline in the incidence of PUB and its complications since the introduction of PPIs and $H$. pylori eradication therapy. A 
lower incidence was observed in Sweden from 1987 to 2004 in both men and women, and one study conducted in the Netherlands found a decline from $61 / 100,000$ to $48 / 100,000$ per year from 1993 to $2000^{17}$. In Germany and the United Kingdom, the incidence of PUB has remained unchanged, but the average patient age has increased ${ }^{18,19}$. In the Zagreb County, Croatia, the incidence of UGIB and PUB did not significantly change from 2008 to 2012. This can be explained by the lower prevalence of $H$. pylori infection and increased use of drugs that affect the cytoprotective function of gastric mucosa (NSAIDs and acetylsalicylic acid), which has also been shown in other studies $^{20}$. The average patient age in this study was higher than 65 years. In one study, Van Leerdam found that $70 \%$ of patients with UGIB were older than 60 years and $40 \%$ had several life-threatening diseases ${ }^{4}$, and in another one Van Leerdam et al. report that about 50\% of patients with PUB were taking NSAIDs and acetylsalicylic acid, with only $12 \%$ of them taking PPI as protection ${ }^{17}$. H. pylori infection was diagnosed in $40 \%$ of patients and was found more frequently in patients with bleeding duodenal ulcers. In one prospective study conducted in the Netherlands, $H$. pylori testing was performed in $65 \%$ of patients with $43 \%$ having positive findings, while a German study found that $56 \%$ of patients with PUB were $H$. pylori positive ${ }^{18,21}$. Gralnek et al. found that PUB made up $28 \%$ to $59 \%$ of all UGIB. Half of the patients were categorized as high-risk ulcer patients (Forrest Ia, Ib, IIa and IIb) ${ }^{22}$. In a study by Bratanic et al., around $30 \%$ of patients were described as high-risk ${ }^{23}$. In our study, PUB represented about $40 \%$ of all non-variceal UGIB, and bleeding gastric ulcers were found more frequently than bleeding duodenal ulcers. Rebleeding after endoscopic treatment with endoclips or endoclips/diluted epinephrine occurred in $10 \%$ of patients and $5.9 \%$ of them required surgical intervention. The risk of recurrent bleeding was increased in patients with shock, actively bleeding ulcers, and ulcers larger than $2 \mathrm{~cm}$ in diameter. Our results are consistent with the results from other tertiary centers, and despite all endoscopic methods for hemostasis available, acute recurrent hemorrhage is still common, occurring in $10 \%$ to $28 \%$ of cases ${ }^{24,25}$. We report a total 30 -day mortality of 5.2\%. Only $10 \%$ of patients died because of bleeding out, while others died from other comorbidities. Mortality was increased in patients with shock, recurrent bleeding ulcers larger than $2 \mathrm{~cm}$ in diameter, and moderate to severe comorbidities (ASA $\geq 3$ ). Almost $60 \%$ of patients with PUB presented with moderate to severe comorbidities (ASA III and IV). When considering other studies, Marmo et al. report a PUB mortality rate of $4 \%$ to $5 \%$ in one prospective study ${ }^{26}$. Van Leerdam et al. showed that $40 \%$ of patients that died because of UIGB had one or several life-threatening comorbidities $^{17}$. Marmo et al. showed that in the first 24 hours of hospitalization, less than $30 \%$ of all patients $\operatorname{died}^{26}$. Villauneva et al. compared the efficacy of a restrictive transfusion strategy (target hemoglobin $7-9 \mathrm{~g} / \mathrm{dL}$ ) with that of a liberal transfusion strategy (target hemoglobin 9-11 g/dL) in patients with acute gastrointestinal bleeding, finding that the probability of survival at 6 weeks was higher in the restrictive-strategy group $^{27}$. This was also observed in a subgroup analysis of patients with PUB. Other authors also suggest better patient outcomes when the restrictive red blood cell transfusion strategy is used ${ }^{8,28-30}$. In our study, half of the patients received red blood cell transfusions, with a median of 2.2 units.

The limitations of this study included diverse medical staff involved in endoscopic evaluation and treatment, resulting in inter-observer variability in endoscopic evaluation and treatment. Furthermore, this study had a short follow-up period of 30 days and was conducted in a tertiary center.

In conclusion, the incidence of UGIB and PUB remained unchanged in the observed period from 2008 to 2012, but we recorded an increase in the average age of PUB patients. Predictors of mortality in patients with PUB included shock, recurrent bleeding, ulcers larger than $2 \mathrm{~cm}$ in diameter, and moderate to severe comorbidities. Prevention of PUB, prompt intravascular volume replacement, early ( $\leq 24$ hours) upper GI endoscopy, and a restrictive red blood cell transfusion strategy are important in the management of these patients.

\section{References}

1. Laine L, Peterson WL. Bleeding peptic ulcer. N Engl J Med. 1994;331(11):717-27, http://dx.doi.org/ 10.1056/ NEJM199409153311107

2. Holster IL, Kuipers EJ. Management of acute nonvariceal upper gastrointestinal bleeding: current policies and future perspectives. World J Gastroenterol. 2012;18:1202-7, http://dx.doi.org/ 10.3748/wjg.v18.i11.1202

3. Budimir I, Nikolić M, Supanc V, Ljubičić N, Krpan T, et al. Secondary arterio-enteric fistula: case report and review of the literature. Acta Clin Croat. 2012;51:79-82. 
4. van Leerdam ME. Epidemiology of acute upper gastrointestinal bleeding. Best Pract Res Clin Gastroenterol. 2008;22: 209-24, http://dx.doi.org/10.1016/j.bpg.2007.10.011

5. Laine L, McQuaid KR. Endoscopic therapy for bleeding ulcers: an evidence-based approach based on meta-analyses of randomized controlled trials. Clin Gastroenterol Hepatol. 2009;7:33-47, http://dx.doi.org/10.1016/j.cgh.2008.08.016

6. Laine L, Jensen DM. Management of patients with ulcer bleeding. Am J Gastroenterol. 2012;107:345-60, http://dx.doi.org/10.1038/ajg.2011.480

7. Khamaysi I, Gralnek IM. Nonvariceal upper gastrointestinal bleeding: timing of endoscopy and ways to improve endoscopic visualization. Gastrointest Endosc Clin North Am. 2015;25: 443-8, http://dx.doi.org/10.1016/j.giec.2015.03.002

8. Gralnek IM, Barkun AN, Bardou M. Management of acute bleeding from a peptic ulcer. N Engl J Med. 2008;359:928-37, http://dx.doi.org/10.1056/NEJMra0706113

9. Saeed ZA, Cole RA, Ramirez FC, Schneider FE, Hepps KS, et al. Endoscopic retreatment after successful initial hemostasis prevents ulcer rebleeding: a prospective randomized trial. Endoscopy. 1996;28:288-94.

10. Hearnshaw SA, Logan RF, Lowe D, Travis SP, Murphy MF, et al. Acute upper gastrointestinal bleeding in the UK: patient characteristics, diagnoses and outcomes in the 2007 UK audit. Gut. 2011;60:1327-35, http://dx.doi.org/10.1136/gut.2010.228437

11. Marmo R, Rotondano G, Bianco MA, Piscopo R, Prisco A, et al. Outcome of endoscopic treatment for peptic ulcer bleeding: is a second look necessary? A meta-analysis. Gastrointest Endosc. 2003;57:62-7.

12. Sadic J, Borgström A, Manjer J, Toth E, Lindell G. Bleeding peptic ulcer - time trends in incidence, treatment and mortality in Sweden. Aliment Pharmacol Ther. 2009;30:392-8, http://dx.doi.org/10.1111/j.1365-2036.2009.04058.x

13. Lau JY, Barkun A, Fan DM, Kuipers EJ, Yang YS, et al. Challenges in the management of acute peptic ulcer bleeding. Lancet. 2013;381:2033-43, http://dx.doi.org/10.1016/S01406736(13)60596-6

14. Hearnshaw SA, Logan RF, Lowe D, Travis SP, Murphy MF, et al. Use of endoscopy for management of acute upper gastrointestinal bleeding in the UK: results of a nationwide audit. Gut. 2010;59:1022-9, http://dx.doi.org/10.1136/gut.2008.174599

15. Bardou M, Benhaberou-Brun D, Le Ray I, Barkun AN. Diagnosis and management of nonvariceal upper gastrointestinal bleeding. Nat Rev Gastroenterol Hepatol. 2012;9:97-104, http://dx.doi.org/10.1038/nrgastro.2011.260

16. Forrest JA, Finlayson ND, Shearman DJ. Endoscopy in gastrointestinal bleeding. Lancet. 1974;2:394-7.

17. van Leerdam ME, Vreeburg EM, Rauws EA, Geraedts AA, Tijssen JG, et al. Acute upper GI bleeding: did anything change? Time trend analysis of incidence and outcome of acute upper GI bleeding between 1993/1994 and 2000. Am J Gastroenterol. 2003;98:1494-9, http://dx.doi.org/10.1111/j.1572-0241.2003.07517.x

18. Ohmann C, Imhof M, Ruppert C, Janzik U, Vogt C, et al. Time-trends in the epidemiology of peptic ulcer bleeding. Scand J Gastroenterol. 2005;40:914-20, http://dx.doi.org/10.1080/00365520510015809
19. Lim CH, Vani D, Shah SG, Everett SM, Rembacken BJ. The outcome of suspected upper gastrointestinal bleeding with 24-hour access to upper gastrointestinal endoscopy: a prospective cohort study. Endoscopy. 2006;38:581-5, http://dx.doi.org/10.1055/s-2006-925313

20. Huang JQ, Sridhar S, Hunt RH. Role of Helicobacter pylori infection and non-steroidal anti-inflammatory drugs in pepticulcer disease: a meta-analysis. Lancet. 2002;359:14-22, http://dx.doi.org/10.1016/S0140-6736(02)07273-2

21. Ramsoekh D, van Leerdam ME, Rauws EA, Tytgat GN. Outcome of peptic ulcer bleeding, nonsteroidal anti-inflammatory drug use, and Helicobacter pylori infection. Clin Gastroenterol Hepatol. 2005;3:859-64.

22. Gralnek IM, Dumonceau JM, Kuipers EJ, Lanas A, Sanders DS, et al. Diagnosis and management of nonvariceal upper gastrointestinal hemorrhage: European Society of Gastrointestinal Endoscopy (ESGE) Guideline. Endoscopy. 2015;47(10): a1-a46, http://dx.doi.org/10.1055/s-0034-1393172

23. Bratanic A, Puljiz Z, Ljubicic N, Caric T, Jelicic I, et al. Predictive factors of rebleeding and mortality following endoscopic hemostasis in bleeding peptic ulcers. Hepatogastroenterology. 2012;60:112-7, http://dx.doi.org/10.5754/hge11838

24. Cipolletta L, Bianco MA, Marmo R, Rotondano G, Piscopo R, et al. Endoclips versus heater probe in preventing early recurrent bleeding from peptic ulcer: a prospective and randomized trial. Gastrointest Endosc. 2001;53:147-51.

25. Lanas A, Aabakken L, Fonseca J, Mungan ZA, Papatheodoridis $\mathrm{GV}$, et al. Clinical predictors of poor outcomes among patients with nonvariceal upper gastrointestinal bleeding in Europe. Aliment Pharmacol Ther. 2011;33:1225-33, http://dx.doi.org/10.1111/j.1365-2036.2011.04651.x

26. Marmo R, Del Piano M, Rotondano G, Koch M, Bianco MA, Zambelli A, Di Matteo G, et al. Mortality from nonulcer bleeding is similar to that of ulcer bleeding in high-risk patients with nonvariceal hemorrhage: a prospective database study in Italy. Gastrointest Endosc. 2012;75:263-72, http://dx.doi.org/10.1016/j.gie.2011.07.066

27. Villanueva C, Colomo A, Bosch A. Transfusion for acute upper gastrointestinal bleeding. N Engl J Med. 2013;368:1362-3, http://dx.doi.org/10.1056/NEJMc1301256

28. Jairath V, Hearnshaw S, Brunskill SJ, Doree C, Hopewell S, Hyde C, et al. Red cell transfusion for the management of upper gastrointestinal haemorrhage. Cochrane Database Syst Rev. 2010:8:CD006613, http://dx.doi.org/10.1002/14651858. CD006613.pub3

29. Laursen SB, Jørgensen HS, Schaffalitzky de Muckadell OB, Danish Society of Gastroenterology and Hepatology. National consensus on management of peptic ulcer bleeding in Denmark 2014. Dan Med J. 2014;61:B4969.

30. Restellini S, Kherad O, Jairath V, Martel M, Barkun AN. Red blood cell transfusion is associated with increased rebleeding in patients with nonvariceal upper gastrointestinal bleeding. Aliment Pharmacol Ther. 2013;37:316-22, http://dx.doi.org/10.1111/apt.12170 


\section{Sažetak}

\section{KRVARENJE IZ PEPTIČKOG VRIJEDA - ISKUSTVA TERCIJARNOG CENTRA: EPIDEMIOLOGIJA, LIJEČENJE I PROGNOZA}

\section{Budimir, S. Stojsavljević, D. Hrabar, D. Kralj, A. Bišćanin, L.S. Kirigin, M. Zovak, Ž. Babić, S. Bohnec i I. Budimir ml.}

Cilj ove studije bio je prikazati epidemiološke, kliničke i endoskopske karakteristike akutnog krvarenja iz gornjeg probavnog sustava s naglaskom na krvarenje iz peptičkog vrijeda. U studiju je bilo uključeno 2198 bolesnika koji su pregledani u hitnoj službi naše ustanove zbog akutnog krvarenja iz gornjeg probavnog sustava u razdoblju od siječnja 2009. do prosinca 2012. godine. Svim bolesnicima je učinjena hitna gastroskopija unutar 24 sata od prijma, a u 842 bolesnika kod kojih je dokazana peptička ulkusna bolest nastavljeno je kliničko praćenje. Kumulativna incidencija krvarenja je bila 126/100.000 u razdoblju od 5 godina. Dva od pet bolesnika su imali krvareći peptički vrijed; ukupno $440(52,3 \%)$ bolesnika je imalo krvareći želučani vrijed, $356(42,3 \%)$ duodenalni vrijed, 17 (2\%) želučani i duodenalni vrijed, a 29 (3,5\%) krvareći vrijed na gastroenteralnoj anastomozi. Srednja dob bolesnika je bila 65,9 godina. Većina bolesnika je uzimala lijekove koji suprimiraju citoprotektivne funkcije želučane i duodenalne sluznice (57\%). Recidiv krvarenja zabilježen je u 77 (9,7\%) bolesnika, a 47 $(5,9 \%)$ je zahtijevalo kiruršku intervenciju. Smrtnost kroz 30 dana je bila 5,2\%, a 10\% bolesnika je umrlo zbog krvarenja i pratećih komorbiditeta. Krvarenje iz peptičkog vrijeda je najčešći uzrok krvarenja iz gornjeg probavnog sustava, a obilježeno je značajnom stopom recidiva krvarenja i smrtnosti.

Ključne riječi: Gastrointestinalno krvarenje - epidemiologija; Gastrointestinalno krvarenje - terapija; Peptički vrijed, krvarenje - epidemiologija; Pepticki vrijed - terapija; Endoskopija, gastrointestinalna; Prognoza; Tercijarni zdravstveni centri; Hrvatska 